\title{
Budaya Bertoilet: Duduk atau Jongkok?
}

\author{
Triyatni Martosenjoyo \\ Dosen Pada Departemen Arsitektur Fakultas Teknik Universitas Hasanuddin \\ triyatni@gmail.com
}

\begin{abstract}
Public toilet is one of the important parts of the building that many aspects of design have to be taken into account to build. Many public toilets are built just by looking at the outer performance without considering whether or not the target user will fit with the design. This article deals with this. It examines how toilet is perceived by the users, what type of toilet is preferred and why, and how they utilize public toilet. The interaction between western and eastern culture in the toilet design has resulted in cultural shock and stuttering technology among the toilet users in regard to the use of toilet because the influx of western culture is not balance with the introduction of the new culture. Whether one chooses squatting or sitting toilet, it is not only related to universal issues about modernity, luxury, cleanliness, and health. Toilet is not solely function as a disposal waste container, but it is also a place for one to seclude him/herself from others, to relax and to create new ideas. Toilet is a symbol to show ones' identity. But how one use the toilet is closely associated with one's perception about toilet, gender, health, cleanliness, Islamic ethics, and body proportion.
\end{abstract}

Key words: toilet, sitting toilet, squatting toilet, modernity.

\section{Pendahuluan}

Sejarah menunjukkan bahwa produk arsitektur pertama lahir karena kesadaran fungsi untuk mewadahi kebutuhan aktifitas manusia. Setelah itu peradaban manusia baru memikirkan teknologi untuk memperkokoh wadah, dan kemudian estetika untuk mengekspresikan cita rasa. Sejak masa Vitruvius, fungsi, teknologi, dan estetika inilah yang saling berinteraksi dan terwujud sebagai karya arsitektur (Vitruvius 1914).

Secara universal dalam menjalankan aktivitas hidup sehari-hari, semua makhluk hidup, termasuk manusia, wajib membuang limbah tubuh mereka. Namun, bagaimana cara manusia membuang limbah tubuh mereka selalu bersifat kontekstual, sangat dipengaruhi oleh bagaimana mereka memaknai hal-hal yang terkait dengan limbah tubuh tersebut. Toilet adalah satu wadah arsitektur untuk mengelola limbah tubuh manusia yang sadar akan martabatnya bahwa mereka berbeda dengan hewan dalam tata cara membuang limbah tubuh mereka.

Manusia menggunakan toilet dipengaruhi dengan bagaimana budaya aktivitas mereka di toilet dan arsitek merancang toilet sesuai dengan budaya tersebut. Masalahnya, para arsitek terbiasa merancang toilet dengan berpatokan kepada standar-standar toilet yang berbudaya toilet negara-negara Barat. Standar-standar tersebut dibuat untuk, antara lain, perilaku duduk mereka saat buang air besar.

Orang-orang berbudaya Barat umumnya melakukan aktivitas bertoilet dengan cara duduk di toilet, sementara orang-orang berbudaya Timur melakukannya dengan cara berjongkok. Ketika arsitek merancang toilet duduk untuk mereka yang berbudaya Timur, dudukan toilet yang dirancang untuk mendudukkan pantat penggunanya, akhirnya menjadi tempat meletakkan kaki/alas kaki pengguna yang jongkok. Tidak terjadi sinkronisasi antara rancangan dengan penggunaan toilet. Fenomena ini ditemui hampir di semua fasilitas toilet publik di Indonesia.

Toilet duduk (sitting toilet) digunakan dengan cara melekatkan panggul dan duduk pada dudukan atau kursi toilet. Toilet jongkok (squatting toilet), digunakan dengan cara pengguna jongkok dengan posisi telapak kaki masing-masing di sisi kanan dan kiri dari lubang 
toilet dan paha menyentuh perut. Toilet duduk umum digunakan oleh masyarakat Barat, oleh karenanya juga disebut 'toilet gaya Barat'. Toilet dengan gaya jongkok sejak masa kuno umum digunakan oleh masyarakat Asia, seperti India, Jepang, China, hingga Anatoila, sehingga disebut sebagai 'toilet gaya Asia' atau 'toilet gaya Timur' (Genç 2009:27).

Perbedaan persepsi makna antara toilet duduk dan toilet jongkok saat ini umumnya hanya berkisar pada isu-isu tentang: (1) modernitas, dimana toilet duduk dianggap modern, sedangkan toilet jongkok dianggap tradisional (Yu 2012:161-162; Pennycook, 1998:180); (2) kemewahan, dimana toilet duduk dianggap lebih mewah dibanding toilet jongkok (Greed 2003: 212; Williams dkk. 2010:930); (3) kebersihan, dimana penggunaan toilet jongkok dianggap lebih bersih dibanding dengan toilet duduk karena tubuh tidak bersentuhan secara langsung dengan toilet yang potensil sebagai sumber pencemar bakteri atau virus (Ken 2012:241; Barker dan Jones 2005:339:347; Gerba dkk. 1975:229237); dan (4) kesehatan, dimana penggunaan toilet jongkok dipersepsikan lebih sehat dibandingkan dengan toilet duduk karena posisi jongkok saat buang air besar sesuai dengan ergonomik tubuh manusia dan akan membuat pengguna terhindar dari penyakit-penyakit pada area wasir, usus besar dan prostat (Molotch 2010:10; Clark 2011:18; Sohrabi dkk. 2012:2327).

Walaupun demikian pertentangan terkait mana yang lebih baik antara toilet jongkok dan toilet duduk lebih banyak dianggap karena faktor budaya penggunanya. Pengguna berbudaya Timur maupun Barat umumnya merasa kesulitan dan tidak nyaman bila harus menggunakan toilet yang tidak sesuai dengan budaya yang mereka kenal. Bahkan keinginan untuk buang hajat dapat menjadi batal karena bentuk toilet yang dianggap asing bagi penggunanya.

Faktor budaya sangat memengaruhi tingkah laku seseorang. Budaya merupakan jalinan makna berdasarkan pengalaman yang menuntun masyarakat pendukungnya dalam berprilaku (Geertz 1973:145). Dalam konteks penggunaan toilet, apakah toilet jongkok atau toilet duduk, sangat ditentukan dengan konteks teknologi yang berkembang pada masanya di wilayah penggunanya. Sebelum teknologi toilet bilas ditemukan, naluri manusia secara alami membuang hajat di alam bebas dengan cara jongkok. Bagi orang kaya, mereka dapat membuang hajat pada potpot atau jambangan. Di atas pot atau jambangan, dibuat kursi atau dudukan bagi pengguna toilet. Kotoran dalam pot atau jambangan kemudian dibuang oleh pelayan mereka. Duduk di atas toilet juga dianggap nyaman bagi mereka yang mengalami masalah dengan bentuk tubuh. Mereka yang bertubuh tambun, sedang hamil, atau cacat, cenderung sulit melakukan aktifitas dengan jongkok (Anderson 2008:75; Cairncross dkk. 2014:37). Oleh karena itu mereka merasa aman dan nyaman menggunakan toilet sambil duduk.

Pengaruh modernisasi yang identik dengan Barat menampakkan kecenderungan toilet jongkok mulai ditinggalkan oleh masyarakat di kotakota besar di Indonesia. Fenomena ini nampak pada fasilitas toilet publik di gedung-gedung mewah, seperti perkantoran, hotel, pusat-pusat perbelanjaan, dan pusat-pusat hiburan. Hal demikian tidak terjadi di kota-kota besar negara maju, seperti Jepang atau Singapura (De Mente, 2008:79; Patokallio 2008:57). Walaupun tingkat teknologi negara-negara tersebut relatif lebih jauh berkembang dibanding Indonesia dan setara dengan negara-negara Barat, toilet jongkok yang identik dengan budaya Timur masih menjadi salah satu pilihan yang selalu tersedia pada toilet-toilet publik mereka.

Toilet-toilet ruang publik di Indonesia dirancang dengan budaya Barat bergaya duduk, sedangkan pengguna berbudaya Timur terbiasa berjongkok. Akibatnya, pengguna cenderung akan tetap jongkok saat menggunakan toilet duduk. Dengan demikian, dudukan toilet nampak menjadi kotor dengan bekas alas kaki yang tercetak di atasnya. Dudukan toilet berbekas alas kaki ini dipersepsikan oleh pengguna yang akan duduk di toilet sebagai kotor atau tidak terjamin kebersihannya oleh karena bagian tubuh mereka akan melekat dengan dudukan toilet saat beraktifitas. 
Riset ini menemukan bahwa pilihan bertoilet dengan cara duduk atau jongkok yang dikaitkan dengan modernitas (Yu 2012:161-162; Pennycook, 1998:180), kemewahan (Greed 2003:212; Williams dkk. 2010:930), kebersihan (Ken 2012:241; Barker dan Jones 2005:339:347; Gerba dkk. 1975:229-237), dan kesehatan seperti yang telah dilakukan pada penelitian-penelitian sebelumnya tidak sepenuhya tepat. Berbeda dengan studi-studi sebelumnya, studi ini menunjukkan bagaimana modernitas dan kemewahan ternyata juga bisa hadir pada toilet jongkok. Kebersihan dan kesehatan juga tidak selalu menjadi alasan dalam memilih gaya bertoilet. Ada pengguna yang memilih tetap duduk walaupun menyadari bahwa melekatkan panggul langsung pada toilet berpotensi tertular penyakit apapun yang berelasi dengan apa yang melekat di dudukan toilet.

\section{Metode Penelitian}

Lokasi penelitian Universitas Hasanuddin (Unhas) dengan pertimbangan bahwa universitas ini merupakan salah satu institusi besar, dan pusat pendidikan tinggi, khususnya di Kawasan Timur Indonesia yang memiliki sentra-sentra toilet publik yang relatif sangat besar jumlahnya di Indonesia dengan pengguna yang berasal dari latar belakang budaya yang beragam.

Informan 120 orang terdiri dari dosen 25 orang, tenaga kependidikan 26 orang, mahasiswa 47 orang, dan pihak ketiga yaitu rekanan perusahaan jasa kebersihan dan kontraktor 22 orang. Informan dipilih bebas dengan mempertimbangkan keragaman latar belakang dari berbagai unit kerja seperti jurusan, fakultas, dan rektorat.

\begin{tabular}{|c|c|c|}
\hline \multicolumn{3}{|c|}{ Table 1. Informan Penelitian } \\
\hline No. & Jenis Informan & Jumlah \\
\hline 1. & Dosen & 25 \\
\hline 2. & Tenaga kependidikan & 26 \\
\hline 3. & Mahasiswa & 47 \\
\hline 4. & Pihak ketiga & 22 \\
\hline & Jumlah Total & 120 \\
\hline
\end{tabular}

Data dikumpulkan dengan metode: (a) observasi lapangan untuk mendapatkan gambaran umum tentang jejaring toilet publik; (b) wawancara terfokus dan wawancara mendalam kepada dosen, tenaga kependidikan, mahasiswa, dan pihak ketiga untuk mendapatkan informasi mendalam tentang masalah-masalah toilet sejak mulai direncanakan, dibangun, digunakan, dan dipelihara; (c) diskusi kelompok terfokus atau focus group discussion (FGD) dilakukan pada 3 (tiga) kelompok mahasiswa sebagai pengguna toilet terbanyak, memiliki akses terbatas terhadap toilet publik universitas, dan posisi sosial yang relatif paling rendah. Jumlah peserta antara 15-20 orang per FGD. Topik-topik diskusi mencakup bagaimana mereka memaknai toilet dan kebersihan, situasi yang dialami saat membutuhkan toilet, serta bagaimana ritual-ritual yang dilakukan saat bertoilet.

Analisis dilakukan silih berganti dengan proses pengumpulan data. Proses analisis dengan menggunakan metode Spradley (1980) (1) Melakukan analisis domain untuk mendapatkan atmosfir data yang dkumpulkan. Setelah pengumpulan data observasi lapangan, dilakukan analisis domain untuk mendapatkan atmosfir data dan menemukan simbol-simbol budaya dari jejaring toilet publik sebagai bagian dari sistem yang lebih besar yang melibatkan sistem budaya kepercayaan, kekuasaan, kesehatan, industri, dan ekonomi. Sistem toilet memiliki sub-domain yang lebih kecil yaitu sistem pengguna, sistem pengelola, sistem sarana, dan sistem teknologi; (2) Melakukan analisis taksonomi berdasarkan domain-domain yang telah ditemukan untuk mendapatkan taksonomi lengkap dan detail dari fenomena-fenomena gaya bertoilet yang ditemui; (3) Melakukan analisis komponensial untuk menemukan kontras-kontras budaya bertoilet antar domain; (4) Melakukan analisis tema untuk mencari hubungan-hubungan masalah dalam sistem budaya bertoilet secara keseluruhan.

Untuk menunjang konfidensialitas data, maka dilakukan penyamaran identitas informan yang dilakukan melalui 3 tahap: (1) mengumpulkan identitas semua informan dalam satu tabel tersendiri; (2) membuat tabel lain dengan nama samaran (pseudonym) sesuai dengan urutan nama informan pada tabel pertama dan disimpan di berkas yang berbeda; dan (3) merahasiakan asal fakultas/unit dari informan, dan jika menyebut 
fakultas, maka hanya disebutkan sebagai 'salah satu fakultas'.

\section{Perencanaan Toilet}

Konsep dan ide toilet publik Unhas dirancang tahun 1980an oleh biro arsitek Belanda bersama dengan PT Sangkuriang Bandung dengan asumsi bahwa kampus ini akan menjadi salah satu pusat pendidikan tinggi yang modern dan berstandar internasional yang diasumsikan sebagai budaya Barat/Amerika. Secara garis besar konsep dan ide toilet publik Unhas mirip dengan yang tertuang pada buku-buku standar internasional perancangan arsitektur, seperti Time Saver For Building Types (De Chiara \& Callender, 1987:710) atau Architects Data (Neufert \& Neufert 2012:194) (lihat Gambar 1 dan 2).

Penggunaan standar Barat yang identik dengan Amerika dalam perancangan toilet sesungguhnya tidak mengherankan karena ide dan konsep tentang fasilitas toilet sebagai lingkungan yang sehat memang berasal dari Amerika. Hingga awal abad XX, masyarakat Indonesia belum mengenal wadah arsitektur khusus untuk membuang limbah tubuh mereka. Fasilitas toilet diperkenalkan oleh perusahaan multinasional Rockefeller sebagai bagian dari kampanye mereka terhadap pengendalian cacing tambang melalui pendekatan persuasif ke rakyat. Cara ini berbeda dengan yang dilakukan oleh pemerintah kolonial Belanda dengan pendekatan kekuasaan (Gouda 2009:13; Heiser 1936:479). Ahli-ahli Yayasan Rockefeller menentukan standar kualitas konstruksi toilet yang baik harus tahan lama, nyaman, dan bersih (Engel \& Susilo 2014:7; Stein 2009:9-10; Hydrick 1942:74).

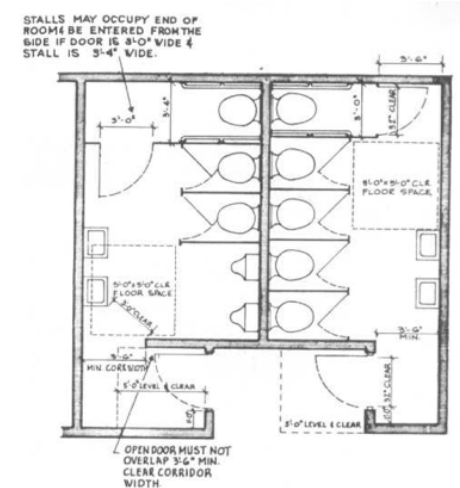

Gambar 1. Pola standar denah toilet publik (Sumber: De Chiara \& Callender 1987:710)

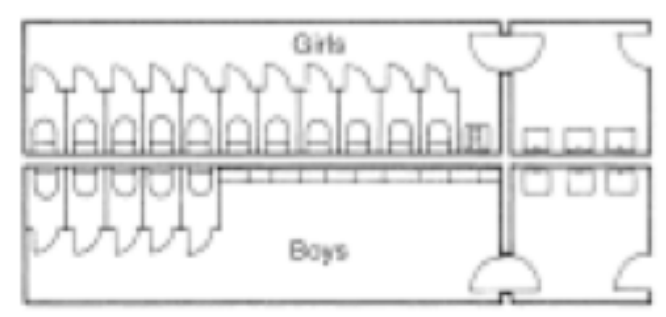

Gambar 2. Pola standar denah toilet publik (Sumber: Neufert \& Neufert 2012:194)

Dari gambar-gambar dokumen perencanaan pembangunan kampus Unhas Tamalanrea yang ada nampak bahwa peruntukan ruang-ruang toilet publik dirancang terpisah berdasarkan gender dan status sosial. Pada pusat toilet lakilaki, hall toilet yang terletak di depan kamarkamar toilet dilengkapi dengan urinoir-urinoir yang digunakan untuk buang air kecil, dan wastafel yang dilengkapi dengan cermin untuk berhias. Pada sentra-sentra toilet perempuan, hall toilet hanya berisi wastafel-wastafel dan cermin untuk mencuci tangan, wajah, dan untuk berhias. Di samping pintu masuk sentra-sentra toilet ada shaft jaringan air bersih dan air kotor (lihat Gambar 3).

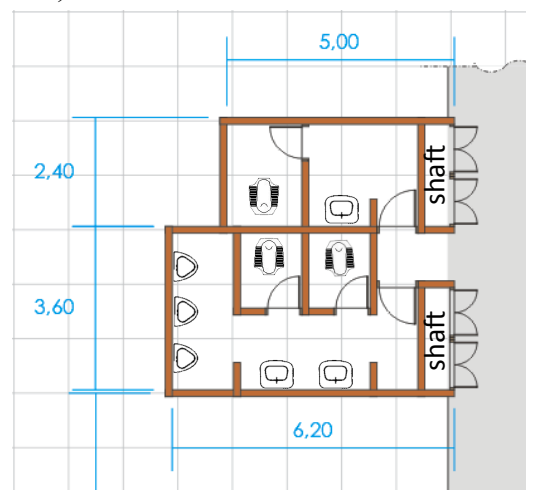

Gambar 3. Pola denah toilet publik Unhas

Perbedaan model toilet publik yang terletak di area pimpinan universitas (rektorat) dan fakultas (dekanat) umumnya adalah toilet duduk, sedangkan di area pendidikan seperti kelas dan laboratorium adalah toilet jongkok. Perbedaan toilet berdasarkan status sosial ini dilakukan dengan asumsi antara lain bahwa (1) Harga toilet duduk lebih mahal dibandingkan dengan harga toilet jongkok. Pejabat rektorat dan dekanat memiliki kelas sosial yang tinggi, sehingga bahan, material, dan teknologi toilet yang mereka gunakan dipilih yang terbaik di masanya; (2) Pemeliharaan toilet duduk relatif lebih sulit 
dibandingkan dengan toilet jongkok, sementara jumlah dan kualitas petugas kebersihan di area pendidikan belum mendapat perhatian memadai dari pihak manajemen; dan (3) Mayoritas mahasiswa pengguna toilet diasumsikan 'kampungan', masih berbudaya jongkok saat buang air besar.

Posisi toilet adalah aspek lain yang menjadi poin penting dalam perencanaan. Banyak posisi toilet di Unhas menghadap ke pintu masuk kamar toilet -berorientasi Timut-Barat- membuat penggunanya akan berhadapan dengan pintu ruang toilet ketika menggunakannya. Belakangan ini sejum toilet publik telah mengalami renovasi dan posisinya tidak lagi menghadap pintu kamar toilet, melainkan berorientasi pada arah UtaraSelatan. Hal ini dilakukan dengan pertimbangan agar pengguna yang beragama Islam tidak membelakangi atau berhadapan dengan arah Kiblat yang secara simbolik merupakan orientasi sholat ummat Islam. Mitos terkait tidak membenarkan buang air dengan membelakangi atau menghadap Kiblat, sebab itu bermakna tidak menghargai simbol-simbol tersebut (Fathi asSayyid Nada 2007:307-308).

Berbeda dengan rancangan toilet duduk yang menggunakan sistem pembilasan otomatis, toilet jongkok di Unhas menggunakan sistem pembilasan manual. Toilet duduk memiliki kontainer air bersih untuk membilas limbah kotoran di toilet. Air bersih akan digelontorkan secara otomatis dengan menekan tombol yang terletak di atas kontainer atau dengan menggerakkan tuas yang terletak di samping kontainer, sesuai spesifikasi masing-masing toilet.

Toilet duduk dilengkapi dengan penutup dan dudukan yang dapat dibuka dan ditutup. Petunjuk penggunaan dari produsen mengatur tata cara menggunakan toilet. Saat buang air kecil bagi laki-laki, penutup dan dudukan diangkat ke atas agar urine dan air bilas tidak membasahi dudukan. Saat buang air besar, penutup dibuka dan dudukan diletakkan di tepi atas bak toilet. Setelah selesai buang air, membilas tubuh dan membilas toilet, penutup dan dudukan toilet diletakkan dalam posisi menutup bak toilet. Dalam praktiknya, sering ditemui dudukan toilet dalam keadaan basah oleh karena tidak diangkat saat laki-laki buang air kecil. Penutup juga sering dibiarkan terbuka ketika pengguna selesai buang air (lihat Gambar 4).

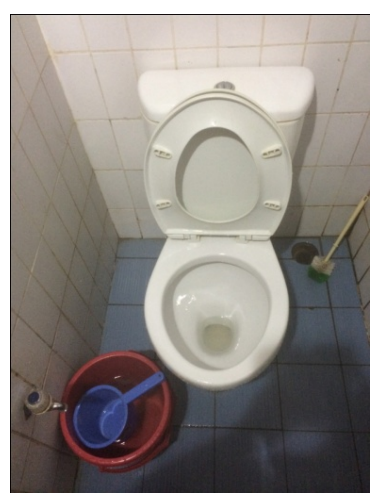

Gambar 4. Toilet duduk dengan sistem pembilas otomatis.

Toilet-toilet duduk yang dibangun 10 tahun terakhir umumnya juga dilengkapi dengan pembilas tubuh otomatis berupa selang fleksibel dengan katup buka tutup air yang terletak di ujung selang. Selang-selang ini di letakkan di samping toilet. Pengguna memakai selang untuk membilas diri dengan posisi duduk di toilet. Dengan demikian, limbah air pembilas masuk langsung ke toilet. Saat selesai membilas tubuh, pengguna kemudian menekan tombol kon-tainer atau menggerakkan tuas untuk membilas toilet.

Pada toilet jongkok, tidak tersedia sistem pembilas tubuh maupun sistem pembilas toilet otomatis. Untuk membilas tubuh, pengguna menimba air dari ember atau kontainer air yang ada di dekat toilet, hal serupa juga dilakukan untuk membilas toilet. Semua toilet jongkok juga tidak dilengkapi dengan penutup toilet (Gambar 5).

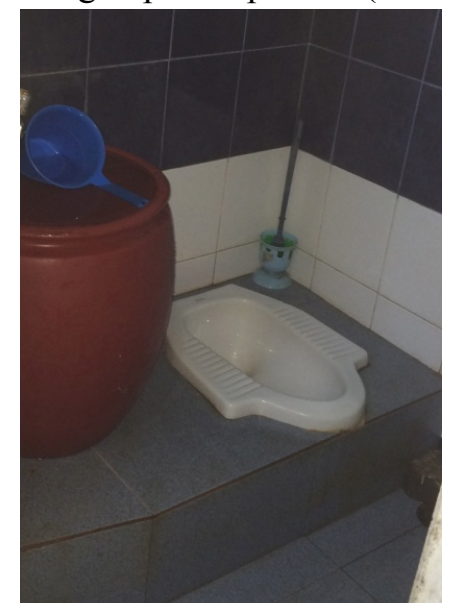

Gambar 5. Toilet jongkok menggunakan pembilas air yang ditimba dari kontainer air di samping toilet. 
Perbedaan teknologi yang digunakan antara toilet duduk dengan jongkok menunjukkan 'seolah-olah' toilet jongkok tidak memiliki teknologi otomatis. Saat diminta membantu untuk memberikan masukan pembuatan toilet salah satu fakultas, saya mengusulkan agar toilet jongkok mereka juga meng-gunakan teknologi yang sama dengan toilet duduk. Dengan demikian pemikiran yang memersepsikan bahwa toilet duduk lebih mewah dibanding toilet jongkok dapat dikontruksi ulang. Bagi pimpinan fakultas, yang paling penting adalah kesan pengguna terhadap kualitas toilet publik mereka 'berkelas'. Semua teknologi otomatis yang ada pada toilet duduk digunakan pada toilet jongkok mereka. Menurut pimpinan fakultas tersebut selain dipuji oleh para tamu, toilet jongkok mereka yang 'berkelas' kemudian menjadi contoh toilet publik bagi para dekan fakultas lainnya (lihat Gambar 6).

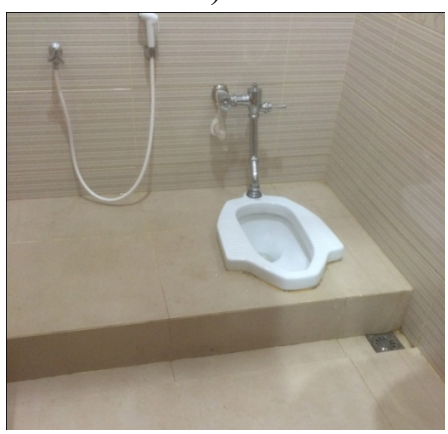

Gambar 6. Toilet jongkok yang dilengkapi dengan pembilas tubuh dan pembilas toilet otomatis.

Saat ini ketika seorang pejabat universitas ditugaskan mengelola rancangan sebuah toilet, maka orang tersebut akan menunjuk konsultan untuk merancang toilet Unhas seperti yang ada di hotel-hotel atau rumah mewah. Model rancangan dan sistem-sistem teknologi toilet dipercayakan kepada konsultan. Staf pengelola tidak mengenal bagaimana sistem-sistem teknologi yang bekerja di balik wajah toilet tersebut. Konsultan yang ditugaskan melihat toilet publik yang dirancangnya sebagai perangkat yang tidak ada hubungan atau tidak terkait dengan sistem-sistem yang lain. Konsultan tidak memikirkan dan menyosialisasikan ke pengelola bagaimana sistem pemeliharaan bila rancangan mereka dibangun. Bila terjadi kerusakan sistem, pengelola memanggil kembali kontraktor untuk memperbaiki kerusakan dengan alasan bahwa mereka yang mengetahui sistem yang dibangunnya. Bila kontraktor sulit dihubungi, perbaikan akan dilakukan oleh staf rumah tangga.

Rudding — seorang teknisi rekanan kontraktor Unhas yang perusahaannya dipercaya mengerjakan semua hal yang terkait dengan pekerjaan fisik melalui sistem penunjukan langsung mulai dari merancang, menghitung biaya, membangun, hingga memelihara fasilitas fisik sesuai yang diinginkan oleh pejabat-menceritakan bahwa dalam proses pekerjaan, biasa-nya mereka dipanggil oleh Bagian Perlengkapan atau oleh pimpinan unit kerja yang membutuhkan pembangunan atau rehabilitasi fasilitas fisik dengan segera. Pejabat terkait hanya memberi petunjuk, misalnya, dengan mengikuti contoh-contoh yang ada di majalah, di hotel-hotel, atau membawa mereka untuk melihat fasilitas sejenis di tempat lain. Rudding kemudian akan membawa berbagai brosur tentang toilet yang ada di perusahaan mereka untuk ditawarkan ke pejabat terkait. Iklan-iklan yang dipromosikan lewat media televisi atau media cetak oleh industri toilet hanya menampilkan budaya Barat dengan gaya duduk. Toilet gaya jongkok hanya dicantumkan sebagai spesifikasi barang pada bagian kecil halaman produk dan tidak dipromosikan sebagai suatu kemewahan.

Bila menemukan proses pekerjaan pemeliharaan nampak sangat rumit dan sulit dan berdampak pada harga yang relatif mahal, Rudding berusaha membuatnya sesederhana mungkin agar mudah mengerjakannya. Misalnya, ketika dudukan toilet terlepas, toilet buntu, atau air tidak mengalir, maka mereka akan 'menebaknebak' atau memeriksa apa penyebabnya. Mereka memilih cara yang paling mudah untuk menyelesaikan masalah, yakni dengan membuat toilet atau saluran baru. Cukup banyak toilet yang dikategorikan tidak berfungsi oleh universitas dan diperbaiki setiap tahun, tetapi masalah-masalah pada toilet tersebut tetap berulang. Misalnya, ke-tidak-berfungsian karena pasokan air yang tidak lancar, saluran yang buntu, asesoris toilet yang hilang. Rudding akan memberi advis untuk merenovasi toilet menjadi 
baru kembali. Ini merupakan siklus pembangunan toilet publik di Unhas.

Apa yang dilakukan perusahaan tempat Rudding bekerja, juga dilakukan oleh perusahaan kontraktor lainnya di Unhas. Masing-masing perusahaan bekerja di Unhas menurut maknamakna budaya yang dibawa dari perusahaan masing-masing. Oleh sebab itu kualitas dan penampilan toilet-toilet publik di Unhas sangat beragam sebagai hasil interaksi antara keinginan pengelola proyek dan kualitas wawasan rekanan yang ditugaskan.

\section{Toilet: Gegar Budaya dan Gagap Teknologi}

Meskipun penggunaan toilet duduk dilakukan dengan cara pengguna membuka penutup toilet dan duduk pada dudukan toilet yang terletak di atas toilet, pada kenyataannya cukup banyak pengguna yang tidak duduk melainkan menaikkan kaki dan jongkok saat menggunakan toilet duduk. Hal ini terlihat pada dudukandudukan toilet yang umumnya memiliki bekas alas kaki yang menempel dan sulit dibersihkan (lihat Gambar 7).

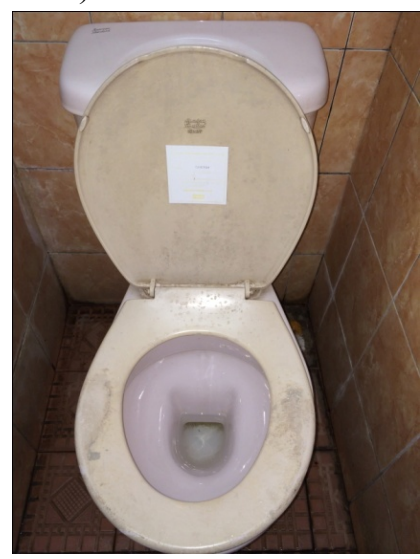

Gambar 7. Bekas kaki pada dudukan toilet.

Pengguna yang memilih jongkok di atas dudukan saat menggunakan toilet duduk antara lain karena mayoritas masyarakat Indonesia memang memiliki budaya jongkok saat buang air. Hingga tahun 2000-an, di Indonesia toilet digunakan sebagai indikator pembangunan 'ketidak-miskinan'. Walaupun sudah memiliki toilet di dalam rumah mereka, banyak masyarakat masih buang air dengan cara jongkok di lapangan, kolam ikan, atau saluran irigasi. Di atas kolam ikan, misalnya, penduduk membuat dudukan toilet (jamban) darurat yang pengguna- nya jongkok di atasnya dan kotoran mereka akan jatuh ke kolam ikan (Mukherjee \& Josodipoero 2000:17; Stein 2009:554).

Orang-orang yang di kampung halamannya berbudaya jongkok saat buang air kemudian menjadi warga Unhas, yang difasilitasi dengan, antara lain, toilet duduk, akan mengalami gegar budaya karena kebingungan dan kehilangan identitas sebagai pengguna toilet yang berbudaya jongkok dengan fasilitas toilet duduk. Akibatnya, mereka tetap menggunakan toilet jongkok saat menggunakan toilet duduk, sebagaimana budaya origin mereka dalam penggunaan toilet.

Identitas adalah sesuatu yang semua orang atau semua kelompok (etnis, ras, nasional) miliki, atau harus memiliki, atau sedang mencari (Brubaker dan Cooper 2000:10). Ketika seseorang bingung tentang siapa dirinya yang sebenarnya, ia akan kehilangan identitas. Kebingungan ini dapat terjadi ketika ia berada di dalam budaya yang berbeda dengan budaya tempat dirinya terbentuk. Perbedaan-perbedaan nilai yang ditemukannya di tempat yang baru, membuat seseorang cemas karena kehilangan orientasi diri berupa tanda-tanda dan simbol keakraban hubungan sosial. Gegar budaya bukan tentang persoalan psikologi individu, melainkan tentang penciptaan dan penyebaran makna (Irwin 2007:2; Oberg 1960:142-144).

Dalam konteks toilet Unhas, seluruh perabot dan asesoris yang hadir pada sentra-sentra toilet publik menggambarkan masuknya budaya material Amerika dalam kehidupan masyarakat Unhas, dimana tidak semua warga telah mengenal dan menjadikan material-material tersebut sebagai budaya mereka di kampung halaman sebelum mereka menjadi warga Unhas. Budaya baru yang ditemui oleh warga Unhas yang baru tersebut tidak diperkenalkan oleh warga yang terlebih dahulu ada di Unhas. Dengan demikian, ketika mereka berhadapan dengan materialmaterial baru tersebut, mereka belajar berinteraksi sesuai dengan pemaknaan mereka sendiri terhadap material-material tersebut, sehingga penggunaan toilet duduk Dianalogikan dengan penggunaan toilet jongkok, yakni dengan berjongkok di atas dudukan toilet duduk. Hal ini sangat biasa terjadi di Indonesia. 
Kondisi Indonesia tersebut di atas berbeda dengan negara Asia lainnya, Jepang misalnya, yang juga menerima masuknya budaya Amerika ke dalam ruang-ruang budaya mereka termasuk pada benda-benda toilet. Mereka segera melakukan pengenalan dan pendidikan kebersihan modern bagi kanak-kanak mereka, termasuk latihan menggunakan toilet. Proses itu dilakukan sejak dini dalam keluarga hingga di sekolahsekolah dasar (Hendry 1992:79-82). Pelatihan toilet bukan hanya dilakukan oleh kanak-kanak Jepang, tetapi juga dilakukan oleh tentara Jepang di luar negeri. Bagi mereka, pelatihan toilet memandu mereka untuk melakukan hal-hal yang benar, pada waktu yang benar, dan di tempat yang benar (Janssens 2005:285-306). Artinya pelatihan toilet bukan sekedar tentang toilet, tapi ada pelajaran yang berkaitan dengan tanggung jawab moral di dalamnya yang terefleksi dalam diri orang Jepang dalam berperilaku.

Selain gegar budaya, ketiadaan masa pengenalan nilai-nilai budaya baru bagi warga pendatang baru Unhas, membuat mereka juga gagap teknologi. Mereka menggunakan bendabenda yang tidak dikenal sebelumnya dengan menggunakan budaya mereka di kampung halaman. Gagap teknologi ini bukan hanya terjadi pada pengguna toilet di tingkat mahasiswa yang dipersepsikan secara umum sebagai kategori 'kampungan', tetapi juga pada dosen, tenaga kependidikan dan petugas kebersihan dari pihak ketiga yang ditempatkan pada manajemen toilet publik sebagai pemelihara aset.

Salah satu contoh gagap teknologi adalah yang terjadi pada fungsi sistem penghematan air yang disediakan pada teknologi toilet duduk. Sistem pembilas pada toilet-toilet yang relatif lama masih menggunakan sistem pembilas tunggal (single flush), sedangkan toilet-toilet yang relatif baru sudah menggunakan pembilas ganda (dual flush). Tombol pada kontainer air toilet menggunakan sistem teknologi pembilas ganda membedakan volume air untuk membilas urine dengan membilas tinja. Dengan sistem pembilas tunggal, kebutuhan air pembilas toilet untuk keperluan buang air kecil atau buang air besar sama-sama menggunakan air 4,5 liter. Dengan sistem pembilas ganda, kebutuhan air pembilas dibedakan untuk buang air kecil menggunakan air 3 liter (tombol bilas kecil, kiri) untuk urin, sedangkan untuk buang air besar menggunakan air 4,5 liter (tombol bilas besar, kanan) untuk kotoran padat (lihat Gambar 8).

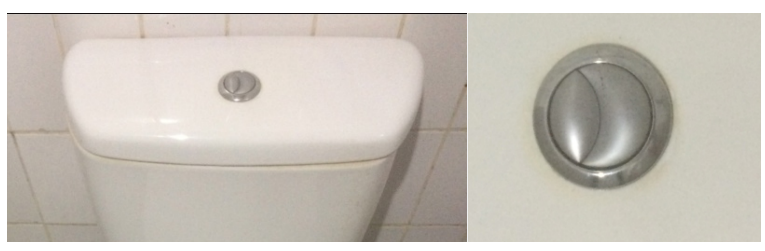

Gambar 8. Sistem dual bilas.

Pada prakteknya, pengguna, perancang, dan pemelihara yang diwawancarai semuanya tidak mengetahui perbedaan fungsi tombol pembilas yang terletak di atas tabung air pembilas, selain sebagai tombol pembilas toilet, dan menekan tombol tersebut tanpa pilihan berdasarkan fungsi masing-masing. Ketika membilas, mereka akan menekan tombol yang mana saja atau bahkan menekan keduanya sekaligus. Bila kotoran belum menggelontor ke lubang pembuangan toilet, maka mereka menekan kembali sampai toilet bersih dari kotoran.

Gagap teknologi juga terjadi pada pengguna laki-laki ketika menggunakan toilet duduk untuk kencing. Jika penutup toilet sedang menutup, mereka akan membuka penutup kemudian kencing. Bila penutup sudah dalam keadaan terbuka, mereka langsung kencing. Namun, pada banyak kasus pengguna toilet yang laki-laki tidak membuka penutup toilet terlebih dahulu sebelum kencing karena merasa jijik dengan pinggiran toilet yang biasanya tidak bersih. Bagi ummat Islam, kencing berdiri tidak sesuai dengan adab (etika) Islam. Sunnah Nabi (berdasarkan HR. al-Bukhari No. 216 dan Muslim no. 292, HR. Ibnu Abi Syaibah No. 121) menyatakan bahwa hendaklah berusaha duduk serendah mungkin (jongkok) saat membuang hajat. Cara seperti itulah yang lebih menutupi aurat dan lebih aman dari percikan air seni yang dapat mengotori badan dan pakaiannya.

Produsen menjual toilet duduk dilengkapi dengan petunjuk penggunaan toilet yang benar saat akan kencing dengan posisi penutup dan dudukan toilet dalam keadaan terbuka. Kencing 
tanpa membuka dudukan toilet menyebabkan tempat dudukan mudah kecipratan dengan urine pengguna. Demikian halnya ketika pengguna laki-laki yang beragama Islam membilas penis mereka, maka air bilasan mencemari dudukan toilet. Cairan dan noda-noda yang nampak secara visual memberi kesan kotor, sehingga pengguna enggan menempelkan panggul mereka dengan duduk langsung di toilet.

Contoh lain gagap teknologi adalah pada sistem pasokan air bersih ke toilet-toilet yang menggunakan sistem otomatis dimana air bersih di tampung pada bak-bak reservoir, dan dialirkan ke penampungan reservoir atas di setiap bangunan. Air kemudian mengalir dengan sistem gravitasi ke unit-unit toilet ketika keran-keran air bersih dibuka. Ketika keran-keran air rusak atau hilang, air mengalir tanpa henti. Petugas kemudian membuat kebijakan seperti di kampung halaman mereka, yaitu dengan menempatkan tangki-tangki air di setiap area toilet. Jadwal pengisian air pada tangki-tangki air dilakukan setiap pagi. Air di tangki ini digunakan saat pasokan air dari reservoir atas dihentikan setelah jam kantor selesai atau ketika pasokan air bersih ke gedung tidak berjalan akibat musim kemarau. Pengguna toilet harus mengambil air dengan ember dan mengangkatnya ke bilik-bilik toilet saat buang air. Ember dan timba air tidak selalu tersedia, sehingga pengguna tidak dapat melakukan proses pembilasan tubuh maupun toilet ketika selesai buang air. Ada pengguna yang melakukan pembilasan tubuh langsung dengan menggunakan keran pada tangki air. Hal ini nampak dari kotoran-kotan yang nampak di sekitar tangki air tersebut. Lihat Gambar 9.

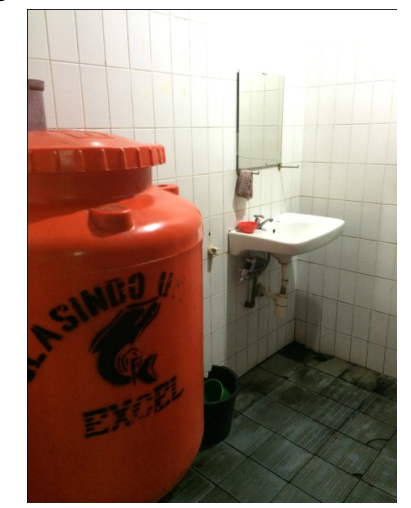

Gambar 9. Tangki air dari PVC fiberglass yang ada di hall-hall toilet.
Dalam keadaan darurat, pengguna terpaksa buang air walaupun toilet dalam keadaan kotor karena kotoran yang tidak terbilas dengan baik. Untuk toilet jongkok tak ada masalah karena pengguna bisa langsung jongkok dan tubuh tidak bersentuhan dengan toilet yang secara visual jelas kotor. Berbeda dengan toilet duduk, pengguna tidak ada yang mau duduk di toilet yang kotor.

Kelman—seorang psikolog sosial-menyelidiki bagaimana proses seseorang dipengaruhi satu sama lain, terutama dalam situasi konflik atau tegang. Setiap proses ditandai dengan serangkaian kondisi pendahuluan yang melibatkan variasi kualitatif tertentu dari seperangkat determinan umum. Kelman mencatat perbedaan antara kepatuhan eksternal dan kesepakatan internal dengan menggambarkan 3 (tiga) jenis perubahan yaitu: kepatuhan; identifikasi; dan internalisasi (Kelman 1958:53). Di Unhas, proses seseorang bertindak saling dipengaruhi satu sama lain baru sampai pada tahap pertama (kepatuhan) dan kedua (identifikasi). Pada proses ini, tindakan-tindakan yang dilakukan bukan karena mereka percaya bahwa muatan perilaku akan menyelesaikan masalah, melainkan hanya untuk menghindari sanksi dan menjaga hubungan timbal-balik. Proses ini belum menyentuh pada tahap ketiga, yaitu internalisasi perilaku baru yang dianggap sebagai cara untuk menyelesaikan masalah yang ada.

\section{Toilet: Sarang Kuman dan Tempat Kotor?}

Fungsi toilet sebagai wadah penampung limbah tubuh manusia menjadikan toilet dipersepsikan sebagai tempat yang kotor atau tidak bersih. Toilet publik adalah tempat berakumulasinya kuman, bakteri, dan virus yang dapat menularkan penyakit berbahaya kepada penggunanya. Umumnya orang beranggapan, bahwa kebersihan dudukan toilet tidak terjamin. Dengan demikian, mereka sangat takut tertular penyakit bila duduk di dudukan toilet duduk. Mereka percaya bahwa penyakit-penyakit kelamin atau AIDS, misalnya, akan mudah menular melalui penggunaan toilet. Meskipun secara intuitif manusia mengetahui bahwa tidak semua kuman berpotensi menularkan penyakit, namun manusia 
tidak memiliki pengalaman langsung terkait dengan kuman tersebut, sampai ilmuwan bersama media mengonstruksikan dan memublikasikan teori kuman secara luas, bagaimana mikroba bertanggungjawab atas berbagai jenis penyakit menular dan bagaimana vaksin dan anti-mikroba menangkal penyakit tersebut (Curtis 2007:663).

Sejarah 'panik kuman' pada tahun 1900, tahun 1940, dan dua decade terakhir tentang AIDS menunjukkan bahwa ide tentang teori kuman penyakit tidak sekedar pada ontologikal dari kuman penyakit itu sendiri, melainkan sebagai konstruksi sosial budaya yang melekat dalam struktur makna lokal. 'Panik kuman' membuat manusia cemas akan ancaman penyakit menular yang dipublikasikan oleh ilmuwan dan media dengan menampilkan banyak aspek budaya popular Amerika, seperti liputan berita, iklan, hingga media hiburan. Kolaborasi antara ilmuwan dan media tersebut dibuat untuk memublikasikan peran ilmuwan bahwa merekalah dengan temuannya yang dapat membunuh kuman-kuman yang mengancam manusia (Tomes 2000:191; Tomes 1998).

Toilet sebagai tempat yang kotor dan jorok juga dipersepsikan melalui bekas kaki yang tercetak di dudukan toilet. Bagi pengguna, bekas kaki dan noda-noda yang nampak secara visual di dudukan toilet ini terasa menjijikkan, sehingga mereka tidak mau melekatkan tubuh mereka dengan dudukan toilet. Melekatkan tubuh dengan dudukan toilet yang kotor dianalogikan dengan membiarkan bagian tubuh menjadi kotor dan dapat menimbulkan penyakit (lihat Gambar 7 di atas).

Jijik adalah sensasi yang mengacu pada sesuatu yang memuakkan. Dalam konteks toilet, sensasi ini dirasakan melalui indera penciuman, sentuhan, hingga penglihatan. Jijik merupakan naluri manusia untuk menghindarkan diri dari ancaman penyakit. Antropolog yakin bahwa ada hubungan antara kebersihan, kotoran, rasa jijik, dan penyakit. Hubungan tersebut yang sudah ada pada ilmu pengetahuan dan sejarah kuno bahkan sebelum manusia diciptakan. Makhluk hidup cenderung menghindari benda-benda yang memungkinkan penyakit berkembang. Setiap gen yang menyukai perilaku higienis cenderung mengungguli yang tidak menyukai (Darwin 1872:257; Curtis 2007:660).

Tenri Ukke-seorang doktor perempuan bangsawan Bugis yang modis dan dosen salah satu fakultas di Unhas - mengisahkan bagaimana ia tidak pernah mampu melakukan aktivitas buang air dengan duduk di toilet. Baginya, ini adalah persoalan psikologis karena budayanya menganggap toilet itu adalah barang yang kotor, termasuk bila toilet itu berada di hotel bintang lima yang kebersihannya selalu terjaga. Setiap menggunakan toilet duduk, ia selalu menaikkan kakinya di atas dudukan toilet. Bila dudukan toilet tersebut dianggapnya tidak bersih, ia akan membersihkan dudukan dengan menyiram air dan menggosok-gosokkan duduk toilet tersebut dengan menggunakan kakinya karena menganggap kakinya bukan sesuatu yang harus dihindarkan dari kotoran, berbeda dengan tangan. Bagian tubuh pribadinya dijaga agar senantiasa bersih dan tidak bersentuhan dengan sesuatu yang dianggapnya tidak suci, yaitu dudukan toilet.

Makna budaya toilet bagi Tenri Ukke serupa dengan yang dikisahkan Sannang tentang perilaku ibunya saat menggunakan toilet. Ibu Sannang tidak pernah bisa menggunakan toilet duduk dan bila terpaksa menggunakan toilet tersebut, ibunya naik ke atas toilet dan jongkok di atasnya. Hal ini selalu dilakukan ketika berada di rumah salah satu anaknya yang hanya memiliki toilet duduk. Ketidak-mampun ibu Sannang menggunakan toilet duduk bukan hanya karena tidak terbiasa dengan budaya duduk di atas toilet, melainkan dikarenakan ibunya tidak ingin bagian pribadi tubuhnya bersentuhan dengan toilet yang dipakai oleh banyak orang. Bagi ibu Sannang, tubuh sekitar alat pembuangan adalah bagian tubuh yang dianggap harus dilindungi dengan baik dan tidak boleh bersentuhan dengan langsung dengan hal-hal yang dianggap asing atau telah digunakan oleh banyak orang.

Persoalan toilet jongkok atau toilet duduk bagi Tenri Ukke dan ibu Sannang menunjukkan bahwa makna bersih atau kotor berkaitan dengan sistem simbol (Douglas 1984:33). Kontak dengan hal-hal yang dianggap kotor, akan mem- 
buat diri seseorang tercemar. Dalam sistem simbol, toilet adalah sesuatu yang tercemar bukan karena virus atau bakteri, melainkan karena dipakai oleh banyak orang. Dengan melekatkan panggul yang merupakan bagian tubuh pribadi pada dudukan toilet yang digunakan oleh banyak orang, diibaratkan dengan membolehkan bagian tubuh pribadi bersentuhan dengan tubuh 'orang lain' yang pernah melekat pada toilet. Toilet dianggap sebagai media yang menghubungkan secara tidak langsung 'tubuh pribadi' pengguna yang secara simbolik dianggap suci dengan tubuh pengguna lainnya (others).

Model busana membuat pemakaian toilet publik bagi pengguna laki-laki lebih merepotkan dibanding pengguna perempuan. Sebelum duduk atau jongkok di atas toilet, pengguna perempuan cukup mengangkat pakaiannya atau menggulung kaki celana dan menurunkan celana yang pinggangnya berkaret. Bagi perempuan pengguna rok mereka kemudian menurunkan celana dalam mereka, dan langsung duduk atau jongkok di atas toilet. Pengguna perempuan harus yakin betul bahwa pakaian mereka tidak akan bersentuhan dengan toilet atau menjadi basah saat membilas tubuh. Proses tersebut dilakukan ketika mereka menggunakan toilet yang dipersepsikan bersih ataupun yang dipersepsikan kotor, untuk buang air kecil maupun untuk buang air besar. Bila tidak yakin, mereka akan membuka pakaian bawah mereka dan menggantungkannya pada gantungan pakaian yang terletak di belakang pintu atau dinding kamar toilet.

Kamar-kamar toilet yang tidak memiliki penggantung membuat pengguna menggantungkan pakaiannya pada pegangan pintu. Pemanfaatan pegangan pintu sebagai tempat menggantung pakaian pengguna memiliki resiko jatuhnya pakaian ke lantai yang basah. Pakaian ini kemudian tidak dianggap bersih lagi dan menghambat pengguna untuk melakukan aktivitas lain, misalnya ritual sholat, yang menuntut pakaian bebas dari najis (baca Khairu 2015:79; Wahf al-Qahthani 2006:41 \& 69; Az-Zabidi 2008:59; Al Jauziyah 2009:23). Dengan menggunakan toilet duduk untuk buang air besar/ buang air kecil atau urinoir untuk buang air kecil, ini dianggap menyalahi sunnah Rasul. Oleh sebab itu, pengguna umumnya memilih pakaian tetap melekat pada tubuh mereka ketika buang air, tetapi menjaganya agar tidak terkena percikan kotoran atau basah saat membilas tubuh.

Bagi pengguna laki-laki yang bercelana panjang, untuk menggunakan toilet dengan cara jongkok saat buang air besar mereka terlebih dahulu membuka kaitan sabuk celana, membuka kancing tarik (retseiting), menurunkan celana panjang, menurunkan celana dalam, dan selanjutnya duduk atau jongkok di atas toilet. Ada pula pengguna laki-laki yang membuka celana luar mereka sebelum menggunakan toilet, agar celana tersebut tidak bersentuhan dengan toilet atau terkena air saat membersihkan tubuh. Saat buang air kecil, mereka cukup membuka kancing tarik dan mengeluarkan penis saat kencing sambil berdiri maupun jongkok.

Pada saat proses membilas tubuh menggunakan timba atau selang pembilas air, pembilas juga akan menciprati dudukan pada toilet duduk. Dengan demikian, pengguna berikutnya akan mendapatkan dudukan toilet dalam keadaan basah. Hal ini menimbulkan persepsi bahwa dudukan toilet yang basah itu 'kotor', karena dianggap bahwa basah juga diidentikkan dengan kotor sehingga pengguna harus membersihkan terlebih dahulu dengan mencucinya dengan air. Pengguna perempuan melapnya dengan kertas tissue bila mereka membawanya. Berbeda dengan membilas tubuh di toilet jongkok. Pengguna tidak memiliki masalah oleh karena cipratan air ke luar mangkuk toilet tidak akan bersentuhan dengan tubuh mereka.

\section{Toilet: Antara Pilihan dan Fungsi}

Pada uraian-uraian sebelumnya telah diketahui bahwa toilet dirancang untuk fungsi mengelola limbah tubuh manusia. Dalam praktiknya, toilet ternyata tidak difungsikan hanya sekedar sebagai tempat membuang hajat. Toilet tak sekedar tempat buang hajat. Sannang, seorang informan mahasiswa yang mengaku berasal dari kampung di salah satu kabupaten Sulawesi Selatan menjelaskan pilihan dia yang lebih suka duduk dibandingkan dengan jongkok 
saat menggunakan toilet. Dia menceritakan bagaimana dia bisa berlama-lama di toilet dengan duduk di atasnya sambil menikmati filmfilm atau videogame yang disukainya melalui smarphone atau tablet. Bagi Sannang, toilet jongkok atau duduk bukan pada mana yang lebih bersih atau lebih kotor, sehat atau tidak sehat, tapi fungsi toilet tergantung pada jenis toilet apa yang digunakan, tak sekedar buang air. Dengan toilet duduk, buang air membutuhkan proses atau waktu yang lebih lama, sehingga waktu tersebut dapat dimanfaatkan untuk santai di ruang toilet. Sannang mempersepsikan toilet bukan sekedar sebagai fasilitas buang air, juga bukan sekedar sebagai gaya hidup, melainkan sebagai media untuk bersantai dimana pengguna dapat berekreasi dan menggali inspirasi tanpa terganggu dengan kehadiran orang lain.

Apa yang dilakukan Sannang di toilet mirip dengan yang dilakukan oleh beberapa elite universitas yang dikelompokkan sebagai 'tangki pemikir' Unhas. 'Tangki pemikir' ini adalah sekelompok dosen dari berbagai fakultas yang pemikiran-pemikirannya digunakan sebagai pengarah kebijakan-kebijakan jangka panjang universitas. Para pemikir ini saling bercerita tentang kenikmatan saat berada di toilet. Disini mereka bisa membaca koran, merokok, mengkhayal, atau berpikir tentang apa saja, termasuk berkontempelasi tentang apa yang telah dan akan mereka lakukan. Semua sepakat bahwa duduk di toilet akan memudahkan bangkitnya ide-ide baru yang sulit diperoleh bila mereka berada di tempat lainnya.

Makna toilet bagi Sannang dan para pemikir bukan hanya sebagai tempat buang air, melainkan sebagai tempat untuk bersantai dan menyendiri tanpa terganggu oleh kehadiran orang lain. Dari seluruh ruang yang ada di dalam bangunan, toilet adalah satu-satunya ruang yang memungkinkan seseorang menyendiri tanpa kehadiran atau gangguan orang lain. Kesendirian jangka pendek di toilet memungkinkan terciptanya situasi kebebasan pribadi seseorang untuk bisa berpikir, bekerja, atau beristirahat, sebagaimana yang diungkapkan Morisy (2011:166-167) mengutip pendapat Marano-penyunting situs daring Psychology Today-bahwa kesendirian sebagai keadaan sendirian tanpa kesepian dan dapat membangkitkan kesadaran diri, memperoleh kedamaian dari kekayaan batin, memberi kesempatan penyegaran untuk memperbaharui diri dalam menghadapi tantangan hidup dan perspektif/ide-ide baru.

Makna toilet sebagai tempat untuk berkontemplasi ini juga menunjukkan bahwa cara pengguna duduk di toilet tidak semata untuk tujuan agar kotoran dengan mudah keluar dari tubuh, seperti isu-isu kesehatan yang bertoilet yang berkembang akhir-akhir ini. Dengan demikian, pilihan bentuk toilet tidak selalu berdasarkan pertimbangan bahwa pilihan toilet jongkok lebih baik oleh karena akan memudahkan kotoran keluar, dibandingkan toilet duduk yang dipersepsikan ilmu kesehatan sebagai menyulitkan. Pilihan akan toilet duduk bagi yang menjadikan kamar toilet sebagai ruang rekreasi atau kontempelasi justru, karena mereka ingin duduk berlama-lama menikmati proses terciptanya ideide baru dari ruang toilet.

Walaupun ada kesadaran untuk membuang air secara jongkok dan dianggap sesuai adab Islam, pengguna Muslim yang memiliki masalah dengan tubuh tambun atau masalah dengan persendian tulang kaki tetap akan memilih duduk sekalipun dudukan toilet dianggap tidak bersih. Mereka juga tidak akan menggunakan toilet jongkok bila tersedia, dikarenakan mengalami kesulitan untuk berdiri kembali setelah jongkok. Mereka juga tidak akan jongkok di toilet duduk walaupun sadar bahwa bila duduk maka tubuh mereka lebih mudah tertular kuman. Mereka takut bila jongkok di toilet duduk maka kaki mereka tergelincir dan tubuh dapat jatuh dari toilet. Oleh sebab itu, walaupun adab Islam menganjurkan untuk jongkok agar sehat, mereka terpaksa memilih duduk dan meletakkan panggulnya langsung bersentuhan dengan toilet. Namun, tidak semua pengguna Muslin yang bertubuh tambun memiliki masalah dengan jongkok di toilet. Mereka umumnya adalah pengguna Muslim yang memiliki latar belakang budaya bersila saat acara-acara budaya etnis atau terbiasa melakukan gerakan-gerakan sholat yang mengharuskan tubuh berdiri, ruku, sujud, dan berdiri kembali. Oleh sebab itu walaupun ber- 
tubuh tambun, mereka tetap mengikuti adab Islam karena tidak mengalami kesulitan saat harus jongkok ketika buang air dan berdiri sesudahnya.

\section{Toilet dan Kekuasaan}

Asumsi-asumsi bahwa mahasiswa umumnya 'kampungan', sehingga cukup disediakan toilet jongkok tidak sepenuhnya tepat. Dalam FGD para mahasiswa saling berkisah bahwa mahasiswa Unhas masa kini cukup banyak yang berbudaya toilet duduk sejak dari rumah mereka. Bila saat ingin buang air dan menemukan dudukan toilet yang kotor, mereka memutuskan untuk tidak jadi buang air. Bagi yang tetap menuntut kebersihan dan saat keinginan untuk buang air tak bisa ditunda, mereka akan mencari dan memanfaatkan toilet-toilet di area rektorat atau dekanat yang masuk daftar 'tidak terkunci'. Untuk toilet-toilet terkunci, ini dapat diakses jika mereka memiliki relasi yang cukup dekat dengan dosen, pegawai, atau petugas kebersihan pemegang kunci toilet.

Kualitas kebersihan toilet di Unhas mengikuti pola kekuasaan patron-klien yang mewujud dalam sistem ajjoareng-joa, dimana ajjoareng (Makassar: karaeng) adalah para bangsawan dan joa adalah golongan orang merdeka (maradeka) yang merupakan pengikut ajjoareng. Joa-joanya disebut dengan ana-ana atau tau-taunna (orangorangnya). (Pelras, 2006:393-394) menyatakan bahwa hubungan patron-klien yang terjadi di Sulawesi Selatan sangat mencolok dalam kehidupan sehari-hari, dan merupakan unsur utama dalam pola-pola masyarakat Bugis-Makassar di Sulawesi Selatan. Di Unhas, elite Unhas diposisikan sebagai ajjoareng oleh oleh oleh para joa yang merupakan pengikutnya.

Pola patron-klien ini hadir secara simbolik dalam bentuk hak akses terhadap sarana fisik universitas. Toilet-toilet bersih hanya hanya bisa diakses oleh jaringan ajjoareng-joa ini (Martosenjoyo 2014:48-49). Dosen, mahasiswa, dan staf biasa yang bukan merupakan elite Unhas tidak memiliki akses terhadap toilet-toilet yang bersih. Oleh karena itu untuk menggunakan toilet-toilet berkualitas baik dan bersih mereka harus menjalin hubungan dengan jaringan kekuasaan ajjoareng-joa yang menguasai aksesakses kekuasaan.

Penguasaan toilet-toilet yang bersih oleh para ajjoareng dan joa-nya tidak diwacanakan dan diproduksi sebagai kebenaran resmi manajemen universitas seperti pada teori wacana kekuasaan (Foucault 1980; Foucault 2000). Secara formal, warga Unhas tetap menyadari bahwa dosen dan mahasiswa memiliki kesetaraan, sehingga semua aturan manajemen toilet dibuat berlandaskan pada kesetaraan tersebut. Kecuali di gedung rektorat yang menyiapkan toilet terpisah untuk rektor, seluruh toilet dirancang untuk fungsi publik. Walaupun demikian, kuatnya relasi ajjoareng-joa di dalam masyarakat Unhas membuat jaringan kekuasaan mereka berperan di dalam manajemen informal Unhas termasuk manajemen toilet. Pada pembangunan kampus Fakutas Teknik di Gowa, perencana merancang toilet dosen yang terpisah dengan mahasiswa. Faktanya, tidak semua dosen bisa menggunakan toilet dosen oleh karena toilet dosen dikunci dan hanya bisa digunakan oleh profesor yang menganggap diri mereka sebagai ajjoareng.

Para pimpinan universitas bercerita tentang larangan penggunaan toilet 'mereka' untuk keperluan publik, bukan karena mereka tidak menganut kesetaraan kelas, melainkan karena alasan bahwa mereka malu bila toilet mereka kotor saat menerima tamu. Berbagi toilet dengan semua orang, terutama mahasiswa yang 'cenderung' jorok, akan membuat toilet mereka kotor. Mereka ingin tamu merasa nyaman saat bertoilet di unit kerja mereka karena toilet yang buruk akan mewakili identitas mereka. Mereka menganggap bahwa memori tamu akan merekam tentang kualitas buruk dari pemimpin yang dikunjunginya ketika mereka menggunakan toilet publik, dan itu sangat memalukan. Itulah sebabnya dibutuhkan toilet pribadi yang juga akan digunakan ketika mereka menerima tamu.

Jaringan kekuasaan yang secara sosial ekonomi dianggap relatif tinggi seperti di gedung rektorat dan gedung dekanat di semua fakultas memiliki toilet duduk, sedangkan yang relatif lebih rendah seperti di Lembaga Penelitian dan Pengabdian Masyarakat (LPPM), jurusan atau 
program studi di semua fakultas memiliki toilet jongkok atau kombinasi toilet duduk dan jongkok. Disini berlaku persepsi bahwa gaya toilet terhubung dengan tingkat sosial ekonomi dan tidak semata-mata dengan budaya pengguna saja. Mereka yang secara sosial ekonomi memiliki status tinggi pasti akan memilih rancangan toilet duduk dan tidak akan memilih rancangan toilet jongkok, karena toilet mereka tidak tampil hanya untuk fungsi melayani mereka membuang limbah, tetapi juga untuk 'dipertontonkan' kepada tamu mereka. Ini serupa dengan kisah orang-orang kaya di Banyumas yang memiliki toilet tetapi tidak digunakan sebagai tempat membuang limbah tubuh mereka, tapi untuk dipamerkan kepada orang-orang bahwa pemiliknya bukanlah orang miskin (Stein 2009:554).

\section{Kesimpulan}

Pada dasarnya budaya masyarakat Indonesia untuk jongkok saat buang air dan duduk di toilet merupakan interaksi masyarakat dengan budaya modern yang identik dengan Barat/Amerika sebagai pemasok budaya toilet. Temuan penelitian ini menunjukkan bahwa interaksi budaya penggunaan toilet menghasilkan gegar budaya (seperti jongkok di atas dudukan toilet duduk) dan gagap teknologi karena masuknya budaya toilet bergaya Barat ke dalam masyarakat Indonesia tidak diimbangi dengan proses pengenalan budaya baru tersebut (seperti penggunaan tombol pembilas tunggal atau ganda atau keduanya sekaligus). Masyarakat menggunakan toilet yang dirancang dengan konsep Barat yang berbudaya duduk saat bertoilet sesuai dengan pemaknaan berbudaya jongkok di budaya mana mereka hidup.

Pilihan jongkok atau duduk di toilet oleh pengguna tidak hanya terkait dengan isu-isu universal tentang modernitas, kemewahan, kebersihan, dan kesehatan. Toilet tak sekedar berfungsi sebagai wadah membuang limbah, tetapi juga sebagai tempat untuk menyendiri tanpa terganggu oleh orang lain (misalnya, tempat bersantai seperti pada kasus Sannang dan melahirkan ide-ide baru seperti pada kasus salah satu 'think tank' Unhas).
Toilet juga merupakan simbol status pemiliknya (seperti toilet duduk identik dengan kemewahan dan modernitas, toilet jongkok identik dengan kemiskinan dan kampungan). Namun, bagaimana seseorang menggunakan toilet sangat berkaitan dengan pertim-bangan yang bersangkutan terhadap persepsi tentang toilet, gender, kesehatan, kebersihan, adab Islam, dan proporsi tubuh mereka.

Penelitian ini menunjukkan bahwa rancangan toilet publik di Indonesia yang selama ini ditawarkan dan dilakukan oleh para arsitek berbasis pada standar Barat/Amerika tanpa kajian tentang bagaimana masyarakat pengguna toilet tersebut memaknai toilet yang akan digunakan sesuai konteks budaya mereka. Pengguna memiliki hak untuk bertoilet sesuai dengan budaya bertoilet mereka dan para arsitek wajib menghormati budaya mereka agar toilet dan penggunanya saling bersinergi.

\section{Daftar Pustaka}

Al-Jauziyah, I. 2009. Ringkasan Zad al Ma'ad (Diterjemahkan oleh M. Sahidu). Islamhouse.com.

Anderson, B. 2008. Streching (Peregangan). Jakarta: PT. Serambi Ilmu Semesta.

Az-Zabidi, I. 2008. Ringkasan Shaih Al-Bukhari (Al-Tajrid Al-Shahia li Ahadits Al-Jami Al-Shahih (Diterjemahkan oleh C. H. Syamsul, \& T. Anis, Murtadha). Bandung: PT. Mizan Pustaka.

Barker, J., \& Jones, M. V. 2005. 'The Potential Spread of Infection Caused by Aerosol Contamination of Surfaces After Flushing a Domestic Toilet'. Journal of Applied Microbiology, 99(2), 339-347.

Brubaker, R., \& Cooper, F. 2000. 'Beyond 'Identity': Theory and Society', Journal Theory and Society, (29), 1-47.

Cairncross, S., Cumming, O., Schechtman, L., Velleman, Y., \& Waddington, H. 2014. Health Impacts of Sanitation and Hygiene, dalam P. Cross, \& Y. Coombs (eds.), Sanitation and Hygiene in Africa, Where Do We Stand? Analysis from the AfricaSan Conference, Kigali Rwanda. London: IWA Publishing, 21-27. 
Clark, C. 2011. No Shit, The History of Wiping A Book You Can Wipe Your Butt It! Caleb Clark on Lulu.com.

Curtis, V. 2007. 'Dirt, Disgust, and Disease: A Natural History Of Hygiene'. Jurnal Epidemiol Community Health 61(8), 660664.

Darwin, C. 1872. The Expression of The Emotion In Man and Animals. London: John Murray.

De Chiara, J., \& Callender, J. 1987. Times Savers Standars for Building Types. Singapore: McGraw-Hill Inc.

De Mente, B. L. 2008. Etiquette Guide to Japan, Know the Rules That Make the Difference. Tokyo: Tuttle Publishing.

Douglas, M. 1984. Purity And Danger - An Analysis of Concepts of Pollution and Taboo. New York: Routledge \& Kegan Paul, Ltd.

Engel, S., \& Susilo, A. 2014. 'Shaming and Sanitation in Indonesia - A Return to Colonial Public Health Practices?'. Jurnal Development \& Change, 45(1), 157-178.

Fathi as-Sayyid Nada, A. 2007. Ensiklopedia Adab Islam (Vol. 2). Jakarta: Pustaka Imam Ay Syafi'i.

Foucault, M. 2000. Power. Essential Works of Foucault 1954-1984 (Vol. III). New York: The New Press.

Foucault, M. (1980). Power/Knowledge, Selected Interviews \& Other Writings 1972-1977. (C. Gordon, Ed., C. Gordon, L. Marshall, J. Mephan, \& K. Soper, Trans.). New York: Pantheon Books.

Geertz, C. 1983. Local Knowledge. Further Essays in Interpretive Anthropology. New York: Basic Books Inc.

Geertz, C. 1973. The Interpretative of Culture. New York: Basic Books Inc.

Genç, M. 2009. The Evolution of Toilets and Its Current State. Ankara: Graduate School of Natural and Applied Sciences of Middle East Technical University.

Gerba, C., Wallis C, C., \& Melnick, J. 1975. 'Microbiological Hazards of Household Toilets: Droplet Production and The Fate of Residual Organisms'. Journal of Applied Microbiology, 30(2), 229-237.

Gouda, F. 2009. Discipline versus Gentle Persuasion in Colonial Public Health: The Rockefeller Foundation's Intensive Rural Hygiene Work in the Netherlands East Indies, 1925-1940. Amsterdam: University of Amsterdam.

Greed, C. 2003. Inclusive Urban Design, Public Toilet. Oxford: Architectural Press, Elsevier.

Irwin, R. 2007. 'Culture Shock: Negotiating Feelings in the Field'. Anthropology Matters Journal, 9(1), 1-11.

Heiser, V. 1936. An American Doctor's Odyssey: Adventure in Forty Fives Countries. New York: W.W Norton.

Hendry, J. 1992. Becoming Japanese - The World of the Preschool Child. Honolulu: University of Hawaii Press.

Hydrick, J. 1942. Intensive Rural Hygiene Work in the Netherlands East Indies. Netherlands and Netherlands East Indies Councils, Institute of Pacific Relations. New York: Netherlands and Netherlands East Indies Councils, Institute of Pacific Relations.

Janssens, R. 2005. 'Toilet Training, Shame, and the Influence of Alien Cultures: Cultural Anthropologists and American Policy Making Postwar Japan 1944-1945', dalam J. Bremen, \& A. Shimizu (eds.), Anthropology and Colonialism in Asia: Comparative and Historical Colonialism. Richmond: Routledge Curzon, 285-306.

Kelman, H. 1958. 'Compliance, identification, and internalization: Three Processes of Attitude Change'. Journal of Conflict Resolution, 2(1), 51-60.

Ken, J. 2012. Because I Said Sol - The Truth Behind the Myths, and Warnings Every Generation Passes Down to Its Kids. New York: Simon \& Schuters, Inc.

Khairu, S. 2015. Rahasia Kedahsyatan Basmallah Berdasarkan Al-Quran dan asSunnah. Lembar Pustaka Indonesia.

Koocher, G. P. 1977. 'Bathroom Behavior and Human Dignity'. Journal of Personality and Social Psychology, 35(2), 120-121. 
Martosenjoyo, T. 2014. 'Why Are Our University Public Toilets Are Dirty: A Case Study of Unhas Public Toilets', dalam R. Iida , K. Nishijima, N. Fukushima dan T. Futatsuyama (eds.), 2014 Report of Research Collaboration \& Management Support Course for International Research Output Training. Kyoto: Graduate School of Asian and African Area Studies Kyoto University, 41-54

Molotch , H. 2010. 'Introduction: Learning from the Loo', dalam H. Molotch \& L. Norén (eds.), Public Restrooms and The Politics of Sharing. New York: New York University Press, 1-22.

Morisy, A. 2011. Borrowing From The Future A Faith-Based Approach to Intergenerational Equity. New York: Continuum International Publishing Group.

Mukherjee, N., \& Josodipoero, R. 2000. Is it Selling No, A Lifestyle - Learning from Communities with Sanitation Success Stories in Indonesia. Water and Sanitation Program East Asia and Pasific.

Neufert, E., \& Neufert, P. 2012. Neufert Architects Data. Iowa, USA: Blackwell Science.

Oberg, K. 1960. 'Cultural Shock: Adjustment to New Cultural Environments', Journal of Practical Anthropology, 7:177-182.

Patokallio, J. 2008. Wikitravel Singapore. Singapore: Wikitravel Press.

Pelras, C. 2006. Manusia Bugis. Jakarta: Nalar, Forum Jakarta-Paris.

Pennycook, A. 1998. English and the Discourses of Colonialism. London: Routledge.
Sohrabi, S., Malekzadeh, R., Ansari, R., \& Kamangar, F. 2012. 'Squatting and Risk of Colorectal Cancer: A Case-Control Study'. Middle East Journal of Digestive Diseases, 4(1), 23-27.

Spradley, J. 1980. Participant Observation. Holt, Rinehart, and Winston. New York: Holt, Rinehart, and Winston.

Stein, E. A. 2009. 'Sanitary Makeshifts and the Perpetuation of Health Stratification in Indonesia', dalam R. Hahn, \& M. Inhorn (eds.), Bridging Differences in Culture And Society. New York: Oxford University Press, Inc., 541-565

Tomes, N. J. 2000. 'Public Health Then and Now - The Making of a Germ Panic, Then and Now'. Journal of Public Health, 90(2), 191-198.

Tomes, N. J. 1998. The Gospel Of Germs: Men, Women And The Microbe In American Life. Cambridge: Harvard University Press.

Vitruvius. 1914. The Ten Books on Architecture (Diterjemahan oleh Morris Hicky Morgan). Cambridge: Harvard University Press.

Wahf al-Qahthani, S. 2006. Ensiklopedia Shalat Menurut al'Quran dan as-Sunnah (Diterjemahkan oleh Abdul Ghoffar EM). Jakarta: Pustaka Imam Asy Syafi'i.

Williams, C. 2010. Southeast Asia on a Shoestring - Ebook Edition. Lonely Planet.

$\mathrm{Yu}, \quad$ S. 2012. Cahng'an Avenue and the Modernization of Chinese Architecture. Washington: The University of Washington Press. 